\title{
PENGARUH PEMBERIAN PROBIOTIK PLUS HERBAL PADA PAKAN KOMERSIL TERHADAP RETENSI PROTEIN DAN RETENSI LEMAK IKAN NILA MERAH (Oreochromis niloticus)
}

\section{THE EFFECT OF ADDITION PROBIOTIC PLUS HERBAL ON COMMERCIAL FEED TO PROTEIN RETENTION AND FAT RETENTION RED TILAPIA FISH (Oreochromis niloticus)}

\author{
Muhammad Arief, Diatra Faradiba dan Muhammad Anam Al-Arief \\ Fakultas Perikanan dan Kelautan Universitas Airlangga \\ Kampus C Mulyorejo - Surabaya, 60115 Telp. 031-5911451
}

\begin{abstract}
Red tilapia fish (Oreochromis niloticus) is one of the mainstays of the freshwater fishery which is growing rapidly in Indonesia. The production of red tilapia fish fishery experiences a significant increase from year after year which amounting from 567.078 tons in 2011 to become 695.063 tons in 2012 and 909.016 tons in 2013 ( Directorate General of Aquaculture - Ministry of Marine and Fishery, 2014).

The development of red tilapia fish farming were not experiences many issues, but there is one problem that needs to be concern which is about feed problem, the feed that used in aquaculture activities is determine the production costs up to $60-70 \%$ of the total production cost incurred (Jusadi et al., 2004).

Fish farming business are strongly influenced by the availability of sufficient fodder in numbers and quality to support the growth and life sustainability of fish cultivation. Feed plays an important part for the growth of the fish (Wahyudi, 2010). The feed can increase the quality of fish weight with addition of a feed additive. One of the alternatives that can be take is by adding probiotic (Anggraeni, 2012) and herbal ingredients in feed (Ariyanto et al., 2013).

Research results show that the addition of probiotics plus herbs affect the digestibility of protein retention and fat retention red tilapia. Based on the research that has been done, the addition of probiotics plus herbs with a dose of $2 \mathrm{ml} / \mathrm{kg}$ of feed can be used as artificial feed supplement and as an alternative to reduce the production cost of cultivation of red tilapia (Oreochromis niloticus).
\end{abstract}

Keywords : Red Tilapia, Oreochromis niloticus, probiotic plus herbal, digestibility

\section{Pendahuluan}

Ikan nila merah (Oreochromis niloticus) merupakan salah satu komoditas utama perikanan budidaya air tawar yang berkembang pesat di Indonesia. Produksi perikanan budidaya ikan nila merah mengalami peningkatan yang signifikan dari tahun ke tahun yaitu sebesar 567.078 ton pada tahun 2011 menjadi 695.063 ton pada tahun 2012 dan 909.016 ton pada tahun 2013 (Direktorat Jendral Perikanan Budidaya - Kementrian Kelautan dan Perikanan, 2014).

Menurut Haetami dkk. (2008) pakan merupakan salah satu komponen yang mencapai $60-70 \%$ dari total biaya produksi serta menjadi salah satu penentu keberhasilan usaha budidaya, sehingga perlu pengelolaan yang efektif dan efisien. Nilai gizi dalam pakan bergantung pada jumlah ketersediaan zat-zat makanan yang ditunjukkan dari bagian yang hilang setelah pencernaan, penyerapan, dan metabolisme.

Penggunaan probiotik plus herbal diharapkan dapat membantu proses penyerapan nutrisi yang baik pada saluran pencernaan, jika proses penyerapan terganggu maka nutrisi yang diberikan tidak dapat terserap dengan maksimal. Peningkatan daya cerna bermakna pula pada semakin tingginya nutrien yang tersedia untuk diserap tubuh, sehingga retensi protein dan retensi lemak dapat meningkat.

Probiotik adalah suplemen berupa sel-sel mikroba hidup, yang memiliki pengaruh menguntungkan bagi hewan inang yang mengkonsumsinya melalui penyeimbangan mikroba pada intestinalnya (Fuller, 1989).

Menurut Fuller (1992) beberapa peneliti mengkategorikan bahwa Lactobacillus acidophilus, Streptococcus thermophilus dan Bifidobacteria termasuk dalam bakteri asam laktat yang dapat mengubah laktosa menjadi asam laktat.

Penggunaan bahan herbal saat ini mulai diterapkan penggunaannya karena bahan-bahan alami ini lebih ekonomis, mudah didapat dan tidak ada efek samping. Bahan herbal seperti kunyit (Curcuma domestica), kencur (Kaempferia galanga) dan temulawak 
(Curcuma xanthorrhiza) mengandung zat aktif utama yang disebut kurkumin.

Bahan herbal adalah bahan alamiah yang berasal dari tanaman untuk digunakan dalam pengobatan. Bahan herbal yang terdapat pada probiotik mengandung kurkuminoid dan minyak atsiri. Kunyit mengandung kurkumin, lemak, karbohidrat, protein dan vitamin c.

Kandungan kurkumin pada kunyit berfungsi sebagai antioksidan serta dapat meningkatkan palatabilitas (Ariyanto dkk., 2013). Wirahadikusumah, (1985) dalam Gunawan, (2012) menambahkan bahwa, kurkumin dalam temulawak dapat meningkatkan sekresi cairan empedu yang berguna untuk mengemulsikan lemak. Minyak atsiri yang terkandung dalam kunyit, kencur dan temulawak bersifat antibakteri terhadap bakteri patogen (Latief, 2012).

\section{Materi dan Metode}

Peralatan Penelitian

Alat yang digunakan dalam penelitian ini adalah akuarium berukuran $50 \times 30 \times 30 \mathrm{~cm}^{3}$ sebanyak 20 buah, selang dan batu aerasi, air pump, tandon air, seser, timbangan analitik, kertas millimeter, gelas ukur, kantong plastik, gayung, nampan, gunting bedah, kertas saring, thermometer, DO meter, $\mathrm{pH}$ paper dan spuit dengan ketelitian $0,01 \mathrm{ml}$.

Bahan Penelitian

Bahan yang digunakan dalam penelitian ini adalah ikan nila merah (Oreochromis niloticus) yang berasal dari pasar ikan Gunung Sari Surabaya, Jawa Timur dengan ukuran 4-7 cm, air PDAM, pakan komersil PF800 dengan kandungan protein $39-41 \%$, lemak $5 \%$, serat $6 \%$, probiotik komersil bioherb seperti yang tertera pada label mengandung molase, bakteri Lactobacillus acidophilus, Bifidobacterium dan Streptococus thermophilis serta bahan herbal seperti kencur (Kaempferia galanga),kunyit (Curcuma domestica), temulawak (Curcuma xanthorriza) dan lainlain.

Pencampuran probiotik pada pakan dan pembedahan usus

Penelitian akan dilakukan dengan pemeliharaan ikan nila selama 30 hari. Probiotik yang digunakan adalah probiotik cair yang diencerkan terlebih dahulu dengan air sebanyak $200 \mathrm{ml} / \mathrm{kg}$ pakan komersial dengan dosis 0 $\mathrm{ml} / \mathrm{kg}, 2 \mathrm{ml} / \mathrm{kg}, 4 \mathrm{ml} / \mathrm{kg}, 6 \mathrm{ml} / \mathrm{kg}$ dan $8 \mathrm{ml} / \mathrm{kg}$ (Ahmadi dkk., 2012).

Menurut Arief dkk. (2014), pengaplikasian probiotik pada pakan komersial dilakukan dengan cara disemprotkan dan diangin-anginkan selama 30 menit. Jumlah pakan pellet yang diberikan sebanyak $4 \%$ dari biomassa. Selama penelitian berlangsung, ikan uji diberi pakan yang telah dicampur probiotik pada pukul 08.00, 12.00 dan 16.00 WIB.

Perhitungan mengenai retensi protein dilakukan menggunakan metode yang dikembangkan oleh Suprayudi dan Setiawati (2003) serta Viola and Rappaport (1979) untuk perhitungan retensi lemak, yaitu dengan menghitung pertambahan protein dan lemak tubuh dengan protein yang terkonsumsi.

Analisis proksimat dilakukan pada awal dan akhir penelitian. Analisis proksimat awal dilakukan bertujuan untuk mengetahui kadar protein dan kadar lemak ikan awal, sebelum pemberian perlakuan. Sedangkan analisis proksimat akhir bertujuan untuk mengetahui kadar protein dan kadar lemak ikan nila setelah pemberian perlakuan. Tujuan dari analisis proksimat ini adalah sebagai salah satu cara untuk mengetahui peningkatan nilai retensi pada ikan nila sebelum diberikan perlakuan dan sesudah diberikan perlakuan.

\section{Hasil dan Pembahasan}

Retensi Protein Ikan Nila Merah (Oreochromis niloticus)

Hasil uji statistik menunjukkan bahwa penambahan probiotik plus herbal pada pakan berbeda nyata $(\mathrm{p}<0,05)$ terhadap retensi protein ikan nila merah.

Data rata-rata retensi lemak ikan nila dengan pakan yang diberi tambahan probiotik plus herbal terdapat pada Tabel 1.

Hasil rata-rata retensi protein menunjukkan bahwa P1 berbeda nyata dengan P0 $(1,1505 \%)$ tetapi P1 $(4,7659 \%)$ tidak berbeda nyata dengan P2 $(3,3455 \%), \quad$ P3

Tabel 1. Rata-rata retensi protein ikan nila merah (Oreochromis niloticus)

\begin{tabular}{lllc}
\hline Perlakuan & Data Asli $(\%) \pm \mathrm{SD}$ & Transformasi & $\sqrt{\mathrm{y} \pm \mathrm{SD}}$ \\
\hline P0 $(0 \mathrm{ml} / \mathrm{kg})$ & $15051^{\mathrm{b}} \pm 0,9058$ & $1,0726^{\mathrm{b}} \pm$ & 0,9517 \\
P1 $(2 \mathrm{ml} / \mathrm{kg})$ & $4,7659^{\mathrm{a}} \pm 0,8480$ & $2,1830^{\mathrm{a}} \pm 0,9208$ \\
P2 (4 ml $/ \mathrm{kg})$ & $3,3455^{\mathrm{a}} \pm 0,9736$ & $1,8290^{\mathrm{a}} \pm 0,9867$ \\
P3 (6 ml $/ \mathrm{kg})$ & $4,1090^{\mathrm{a}} \pm 2,1089$ & $2,0270^{\mathrm{a}} \pm$ & 1,4522 \\
P4 (8 ml $/ \mathrm{kg})$ & $2,1154^{\mathrm{ab}} \pm 1,3172$ & $1,4544^{\mathrm{ab}} \pm 1,1476$ \\
\hline
\end{tabular}


Tabel 2. Rata-rata retensi lemak ikan nila merah (O. niloticus)

\begin{tabular}{|c|c|c|c|}
\hline Perlakuan & Data Asli & $(\%) \pm \mathrm{SD}$ & Transformasi $\sqrt{\mathrm{y}} \pm \mathrm{SD}$ \\
\hline $\mathrm{P} 0(0 \mathrm{ml} / \mathrm{kg})$ & $2,0605^{b}$ & 1,2150 & $1,4354^{\mathrm{a}} \pm 1,1022$ \\
\hline $\mathrm{P} 1(2 \mathrm{ml} / \mathrm{kg})$ & $3,8759^{\mathrm{a}}$ & 0,8569 & $1,9687^{b}$ \\
\hline $\mathrm{P} 2($ & $3,3889^{a b}$ & 0,3160 & $1,8408^{\mathrm{ab}} \pm$ \\
\hline P3 6 & $5,0710^{a}$ & $\pm 1,7792$ & $2,2518^{\mathrm{a}} \pm$ \\
\hline $\mathrm{P} 4(8 \mathrm{ml} / \mathrm{kg})$ & $2,1154^{\mathrm{ab}}$ & $\pm 0,6677$ & $1,8204^{\mathrm{ab}} \pm$ \\
\hline
\end{tabular}

\section{$(4,1090 \%)$ dan P4 (2,1154\%).}

\section{Retensi Lemak Ikan Nila Merah (Oreochromis niloticus)}

Data rata-rata retensi lemak ikan nila dengan pakan yang diberi tambahan probiotik plus herbal terdapat pada Tabel 2. Dari hasil penelitian didapatkan nilai retensi lemak berkisar 2,0605\% - 5,0710\%.

Hasil rata-rata retensi lemak menunjukkan bahwa $\mathrm{P}_{1}$ berbeda nyata dengan dan $\mathrm{P}_{0}$ tetapi $\mathrm{P}_{1}$ tidak berbeda nyata dengan $\mathrm{P}_{2}$, $\mathrm{P}_{3}$ dan $\mathrm{P}_{4}$. Retensi lemak ikan nila merah pada perlakuan $\mathrm{P}_{1}(3,8759 \%)$ tidak berbeda nyata dengan $\mathrm{P}_{2}(3,3889 \%), \mathrm{P}_{3}(5,0710 \%)$ dan $\mathrm{P}_{4}$ $(2,1154 \%)$, sedangkan pada $\mathrm{P}_{4}(2,1154 \%)$ tidak berbeda nyata dengan $\mathrm{P}_{2}(3,3889 \%)$ dan $\mathrm{P}_{0}$ $(2,0605 \%)$.

\section{Parameter Kualitas Air}

Parameter kualitas air yang diukur selama penelitian adalah suhu, $\mathrm{pH}$ dan oksigen terlarut / Dissolved Oxygen (DO). Pengukuran parameter kualitas air dilakukan pada awal penelitian, setiap 10 hari dan pada akhir penelitian. Pengukuran kualitas air ini bertujuan untuk memantau kondisi kualitas air bagi ikan nila merah (Oreochromis niloticus) selama pemeliharaan. Data nilai kisaran parameter kualitas air pada pemeliharaan ikan nila merah (Oreochromis niloticus) selama penelitian yang dapat dilihat pada Tabel 3.

Tabel 3. Nilai kisaran parameter kualitas air selama pemeliharaan 30 hari

\begin{tabular}{ccc}
\hline Parameter & Satuan & Kisaran \\
\hline Suhu & ${ }^{\circ} \mathrm{C}$ & $25,82-25,95$ \\
DO & $\mathrm{mg} / 1$ & $4,87-8,43$ \\
pH & & $7,23-7,53$ \\
\hline
\end{tabular}

Retensi Protein Ikan Nila Merah (Oreochromis niloticus)

Retensiprotein menunjukkan besarnya kontribusi protein pakan yang dikonsumsi terhadap pertambahan protein tubuh (Ballestraazzi et al., 1994).

Berdasarkan hasil analisa statistik diketahui bahwa penambahan probiotik plus herbal pada pakan menunjukkan hasil yang berbeda nyata $(\mathrm{p}<0,05)$ terhadap retensi protein ikan nila merah.

Pemberian probiotik plus herbal pada pakan dengan dosis $2 \mathrm{ml} / \mathrm{kg}$ pakan memberikan hasil yang paling baik dan dapat meningkatkan nilai retensi protein dibandingkan dengan pakan tanpa pemberian probiotik plus herbal, hal tersebut diduga karena tingginya tingkat penyerapan pada saluran pencernaan yang disebabkan oleh adanya aktivitas bakteri asam laktat yang ada pada probiotik.

Menurut Arief (2008) peranan bakteri asam laktat mampu mengubah karbohidrat menjadi asam laktat yang dapat menurunkan $\mathrm{pH}$, dengan demikian kondisi lingkungan pada saluran pencernaan menjadi suasana asam, sehingga bakteri patogen yang berada pada saluran pencernaan dapat tereliminasi dan proses penyerapan nutrisi dapat berjalan dengan baik tanpa terhalang oleh bakteri patogen.

Bahan herbal yang terdapat pada probiotik mampu meningkatkan palatabilitas dan bersifat anti bakteri terhadap bakteri patogen (Ariyanto dkk., 2013 ; Latief, 2012). Retensi protein pada perlakuan P1 $(4,7659 \%)$ berbeda nyata dengan perlakuan P0 $(1,1505 \%)$ tetapi P1 tidak berbeda nyata dengan P2, P3 dan P4. Perlakuan P4 (3,3139\%) memberikan hasil yang tidak berbeda nyata dengan P0 $(1,1505 \%)$ pakan tanpa pemberian probiotik plus herbal.

Pemberian probiotik plus herbal dengan dosis $8 \mathrm{ml} / \mathrm{kg}$ pakan pada perlakuan $\mathrm{P} 4$ memberikan hasil yang kurang maksimal, hal ini diduga konsentrasi bakteri yang diperlukan terlalu banyak maka akan menimbulkan overgrowth. Menurut Atlas and Richard (1993) bahwa kepadatan bakteri yang tinggi menyebabkan adanya persaingan dalam pengambilan nutrisi sehingga aktivitas bakteri menjadi terhambat. Mulyadi (2011) menambahkan jumlah bakteri yang terlalu banyak menyebabkan bakteri cepat mengalami sporulasi sehingga fungsi dan aktivitas bakteri Lactobacillus sp., menjadi tidak optimal dan proses penyerapan juga menjadi tidak maksimal. 
Perlakuan P1, P2, P3 dan P4 menunjukkan bahwa nilai retensi protein pada ikan nila mengalami peningkatan, hal ini menunjukkan bahwa ikan dapat memanfaatkan pakan yang diberikan secara optimal sehingga bobot tubuh dapat meningkat dikarenakan pakan dapat dicerna secara optimal dan pakan tersebut terserap dalam tubuh dan dapat diubah menjadi daging, hal tersebut diduga disebabkan adanya bakteri probiotik dalam pakan yang kemudian masuk ke dalam saluran pencernaan dan menekan bakteri patogen yang ada dalam usus, sehingga dapat membantu proses penyerapan makanan lebih baik.

Retensi Lemak Ikan Nila Merah (Oreochromis niloticus)

Menurut Agustono dkk., (2007) retensi lemak menggambarkan kemampuan ikan menyimpan dan memanfaatkan lemak pakan. Lemak pakan sangat penting digunakan sebagai energi. Lemak pakan dalam bentuk asam lemak essensial dibutuhkan dalam pertumbuhan dan metabolisme tubuh (NRC, 1993). Fungsi lemak yang lain adalah membantu proses metabolisme dan menjaga keseimbangan daya apung ikan di air (Herawati, 2005).

Retensi lemak pada perlakuan $\mathrm{P}_{1}$ $(3,8759 \%)$ berbeda nyata dengan perlakuan $\mathrm{P}_{0}$ $(2,0605 \%)$ tetapi $\mathrm{P}_{1}$ tidak berbeda nyata dengan $\mathrm{P}_{2}(3,3889 \%), \mathrm{P}_{3}(5,0710 \%)$ dan $\mathrm{P}_{4}(2,1154 \%)$. Perlakuan $\mathrm{P}_{4}(2,1154 \%)$ memberikan hasil yang tidak berbeda nyata dengan $\mathrm{P}_{2}(3,3889 \%)$ dan $\mathrm{P}_{0}$ $(2,0605 \%)$ pakan tanpa pemberian probiotik plus herbal.

Hasil uji statistik perlakuan $\mathrm{P}_{1}, \mathrm{P}_{2}, \mathrm{P}_{3}$ dan $\mathrm{P}_{4}$ menunjukkan bahwa nilai retensi lemak pada ikan nila mengalami peningkatan.

Meningkatnya nilai retensi lemak pada perlakuan $\mathrm{P}_{1}, \mathrm{P}_{2}, \mathrm{P}_{3}$ dan $\mathrm{P}_{4}$ disebabkan oleh aktivitas bakteri asam laktat yang ada pada probiotik plus herbal dapat memberikan suasana asam sehingga bakteri patogen yang tidak tahan pada suasana asam dapat tereliminasi dan proses proses penyerapan nutrisi dapat berjalan dengan baik tanpa terhalang oleh bakteri patogen (Arief, 2008).

Meningkatnya nilai retensi lemak pada perlakuan $\mathrm{P}_{1}, \mathrm{P}_{2}, \mathrm{P}_{3}$, dan $\mathrm{P}_{4}$ juga disebabkan oleh bahan herbal yang terkandung pada probiotik, bahan herbal yang terdapat pada probiotik mengandung kurkuminoid yang dapat membantu proses pencernaan secara maksimal dengan merangsang empedu mengeluarkan garam empedu yang berguna untuk mengemulsikan lemak sehingga mempermudah proses penyerapan lemak.

Wirahadikusumah, (1985) dalam Gunawan, (2012) menjelaskan bahwa, lemak pakan sebagian besar terdiri dari trigliserida atau trigliserol yang harus dipecah terlebih dahulu untuk mempermudah proses reabsorbsi dalam tubuh. Emulsifikasi adalah proses dimana terjadi pengikatan lemak oleh garam empedu, sehingga nantinya dalam bentuk emulsi ini dapat mempermudah proses penyerapan.

\section{Kesimpulan}

Berdasarkan hasil penelitian yang telah dilakukan mengenai penambahan probiotik plus herbal pada pakan komersil, maka dapat ditarik kesimpulan bahwa penambahan probiotik plus herbal pada pakan dapat meningkatkan kecernaan protein kasar dan serat kasar ikan nila merah (Oreochromis niloticus) yaitu pada pada perlakuan P1 (dosis $2 \mathrm{ml} / \mathrm{kg}$ pakan), P2 (dosis 4 $\mathrm{ml} / \mathrm{kg}$ pakan), P3 (6 dosis $\mathrm{ml} / \mathrm{kg}$ pakan) dan $\mathrm{P} 4$ (8 $\mathrm{ml} / \mathrm{kg}$ pakan). Penambahan probiotik plus herbal dengan dosis $2 \mathrm{ml} / \mathrm{kg}$ pakan dapat digunakan sebagai suplemen pakan buatan dan sebagai alternatif mengurangi biaya produksi budidaya ikan nila merah (Oreochromis niloticus). Berdasarkan hasil penelitian yang telah dilakukan disarankan agar dilakukan penelitian mengenai keberadaan bakteri probiotik pada pakan buatan yang telah ditambahkan probiotik dan seberapa besar kandungan herbal yang terdapat pada probiotik tersebut.

\section{Daftar Pustaka}

Afrianto, E. dan E. Liviawaty. 2011. Beberapa Metode Budidaya Ikan. Penerbit Kanisius. Yogyakarta. hal. 14-16.

Ahmadi, H., Iskandar dan N. Kurniawati. 2012. Pemberian Probiotik dalam Pakan terhadap Pertumbuhan Lele Sangkuriang (Clarias gariepinus) pada Pendederan II. Jurnal Perikanan dan Kelautan. 3(4): 100-102.

Arief, M., N. Fitriani dan S. Subekti. 2014. Pengaruh Pemberian Probiotik Berbeda pada Pakan Komersial terhadap Pertumbuhan dan Efisiensi Pakan Ikan Lele Sangkuriang (Clarias sp.). Jurnal Ilmiah Perikanan dan Kelautan. 6(1): 49-53.

Burreau, D. P. and C. Y. Cho. 1999. Measuring Digestibility in Fish. Fish Nutrition Research Laboratory Technical Document. University of Guelph. Canada. Pp. 9.

Direktorat Jendral Perikanan Budidaya Kementrian Kelautan dan Perikanan. 2014. Produksi Perikanan Budidaya Mendukung Perekonomian Nasional dan Meningkatkan Kesejahteraan. 
http://www.djpb.kkp.go.id/berita.php?i $\mathrm{d}=1057$ (diakses tanggal 18 Desember 2014).

Fuller, R. 1989. A Review Probiotic in Man and Animals. J.Appl. Bac. 66: 365-378.

Fuller, R. 1992. History and Development of Probiotics. In Probiotics the Scientific Basis. Edited by Fuller, Chapman and Hall. London. Pp. 1-7.

Haetami, K., Abun, dan Y. Mulyani. 2008. Studi Pembuatan Probiotik BAS (Bacillus licheniformis, Aspergillus niger, dan Sacharomices cereviseae) Sebagai feed supplement serta Implikasinya terhadap Pertumbuhan Ikan Nila Merah. Penelitian. Fakultas Perikanan dan Ilmu Kelautan. Universitas Padjajaran. 53 Hal.

Lovell, T. 1989. Nutrition and Feeding of Fish. New York. Pp. 260

Maynard, L. A., J.K Loosli, H.F Hintz, R.G Warner. 1979. Animal Nutrition. Seventh Edition. Mc Graw-Hill. Book Company. New Delhi. pp. 602.

Mundayana, Y. 2010. Fungsi Gizi dalam Pakan Ikan. Aneka Ilmu. Jakarta. Hal. 27.

NRC. 1993. Nutrient Requirement of Fish. National Academy Press. Washington, D.C. pp. 48.
Pujianti, N. A., A. Jaelani dan N. Widaningsih. Penambahan Tepung Kunyit (Curcuma domestica) dalam Ransum terhadap Daya Cerna Protein dan Bahan Kering pada Ikan Nila (Oreochromis niloticus). ZIRAA'AH 36(1): 49-59.

Rahmat, N. 2008. Penampilan Produksi dan Kualitas Daging Kerbau dengan Penambahan Probiotik, Kunyit dan Temulawak Pada Pakan Penggemukan. Skripsi. Program Studi Teknologi Hasil Ternak. Fakultas Peternakan. IPB. Bogor. $61 \mathrm{Hal}$.

Soeharsono. 2010. Probiotik. Widya Padjajaran. Bandung. Hal.119-123.

Usman, N.N. Palinggi, dan N. A. Giri. 2003. Pemanfaatan beberapa jenis karbohidart bagi pertumbuhan dan efisiensi pakan yuwana ikan kerapu bebek (Cromileptes altivelis). Jurnal Penelitian Perikanan Indonesia 9(2): 21-28.

Watanabe T. 1988. Fish Nutrition and Mariculture. Tokyo: JICA Textbook the general Aquaculture Course. Departement of Aquatic Bioscience. Tokyo University of Fisheries. Pp. 233. 
Pengaruh Pemberian Probiotik Plus...... 